\title{
Integrated mapping of water-related disasters using the analytical hierarchy process under land use change and climate change issues in Laos
}

\author{
Sengphrachanh Phakonkham ${ }^{1}$, So Kazama ${ }^{2}$, and Daisuke Komori ${ }^{2}$ \\ ${ }^{1}$ Department of Environmental Engineering, Faculty of Engineering, National University of Laos, \\ Lao-Thai Friendship Road, Sisattanak District, Vientiane Prefecture, Laos \\ ${ }^{2}$ Department of Civil Engineering, Tohoku University, Sendai, 980-8579, Japan
}

Correspondence: Sengphrachanh Phakonkham (bphrakonkham@gmail.com)

Received: 12 June 2020 - Discussion started: 6 July 2020

Revised: 15 February 2021 - Accepted: 18 March 2021 - Published: 20 May 2021

\begin{abstract}
In the past few decades, various natural hazards have occurred in Laos. To lower the consequences and losses caused by hazardous events, it is important to understand the magnitude of each hazard and the potential impact area. The main objective of this study was to propose a new approach to integrating hazard maps to detect hazardous areas on a national scale, for which area-limited data are available. The integrated hazard maps were based on a merging of five hazard maps: floods, land use changes, landslides, climate change impacts on floods, and climate change impacts on landslides. The integrated hazard map consists of six maps under three representative concentration pathway (RCP) scenarios and two time periods (near future and far future). The analytical hierarchy process (AHP) was used as a tool to combine the different hazard maps into an integrated hazard map. From the results, comparing the increase in the very high hazard area between the integrated hazard maps of the far future under the RCP2.6 and RCP4.5 scenarios, Khammouan Province has the highest increase $(16.45 \%)$. Additionally, the very high hazard area in Khammouan Province increased by approximately $12.47 \%$ between the integrated hazard maps under the RCP4.5 and RCP8.5 scenarios of the far future. The integrated hazard maps can pinpoint the dangerous area through the whole country, and the map can be used as primary data for selected future development areas. There are some limitations of the AHP methodology, which supposes linear independence of alternatives and criteria.
\end{abstract}

\section{Introduction}

Nowadays, natural disasters take a few thousand people's lives around the world and causes losses of about USD 100 billion every year (Sendai Framework, 2015). Additionally, Dilley et al. (2005) found that about 700 million people and about 100 million people in the world are affected by at least two hazards and three or more hazards, respectively. Laos, or Lao People's Democratic Republic (PDR), is a developing country located in Southeast Asia. The citizens depend heavily on agriculture and natural resources for their livelihoods. Currently, the water supply system in the country is not well distributed, particularly in rural areas. Therefore, most people living in rural areas are resettled downstream of dams and irrigation areas (Baird and Shoemaker, 2007). Changes in land use, such as decreases in forest density, can cause increases in flood magnitude (Jongman et al., 2012; Winsemius et al., 2016). In addition, in their study on the effect of land use and land cover change and flood hazard on poverty in Bangladesh, Adnan et al. (2020) argue that disorganized planning for land use can increase flooding and poverty. In recent years, many researchers have conducted global studies on the impact of climate change on the water cycle and its effect on people's livelihoods (Adeloye et al., 2013; Parmesan and Yohe, 2003; Westra et al., 2014). However, there have been only a few assessments and analyses for predictions on the environmental impacts on the country when considering possible climate changes. Shah et al. (2020) simulate surface water under different climate change scenarios using a set of regional circulation models (RCMs) and the Soil and Wa- 
ter Assessment Tool (SWAT) model for mid-century (20402070) and late century (2071-2100). The result of SWAT under future scenarios shows an increase in steamflow for the mid-late-21th century. However, the increase of steam flow for mid-century was a bit higher compared to late century due to the increase of temperature impact on snowfall and accumulation. According to the Intergovernmental Panel on Climate Change (IPCC) report, Southeast Asia will suffer from increasing flood frequency in the future (IPCC, 2007). General circulation models (GCMs) have been developed to study future climate scenarios and the associated impacts, and they help support strategies and mitigation plans to address the effect of climate change.

The effects of hazards on an area could be in either a single or multiple form. In the last decade, the uses of multi-hazard assessment focusing on all scales have been considered in several studies (Cutter et al., 2000; Marzocchi et al., 2012; Sendai Framework, 2015; Sullivan-Wiley and Short Gianotti, 2017). However, exhaustive data are required in most assessments. Recently, geographic information systems (GISs) have been used as a tool for such assessment (Fernández and Lutz, 2010; Kazakis et al., 2015). In contrast, the tool is ineffective in performing multicriteria analyses, and hence it is not appropriate for executive or managerial purposes. Previous studies have presented many methodologies to integrate multiple hazards, such as using classification schemes or providing weighting for each hazard. There are several multicriteria decision-making methods for solving multiple conflicts among independent criteria when evaluating multihazard maps.

The main objective of this study is to propose a reliable hazard map that can identify sensitive areas over the national region, for which limited data are available. This method of modeling combines different hazard maps, including flood, land use change, and climate change maps. The proposed methodology provides an integrated hazard map that can be used as a guide map that provides all of the important information that can be used to develop countermeasures not only for floods but also for other natural hazards. This study is also the first to develop a hazard map for the entire country of Laos. Another advantage of this proposed method is that the analytical hierarchy process (AHP) weights that are used to develop the unified hazard maps are based on the design criteria and priorities of the decision makers. It is helpful for identifying hazard areas and focusing on potential areas of impact.

For instance, multi-attribute utility theory (MAUT) (Keeney and Raiffa, 1993) can decide the best course of action in a given problem by assigning a utility to every possible consequence and calculating the best possible utility. The drawback of this method is the requirement of a large amount of input in every step of the procedure (Konidari and Mavrakis, 2007). Simple additive weight (SAW) (Fishburn, 1967) was established based on a simple addition of scores that represent the goal achievement under each crite- rion, multiplied by the particular weight. The disadvantage of SAW is that the estimated weight does not always reflect the real situation (Qin et al., 2008). The technique for order preference by similarity to ideal solutions (TOPSIS) (Hwang and Yoon, 1981) is an approach to identifying an alternative that is close to an ideal solution and farthest from a nonideal solution in a multidimensional space. For instance, Asadzadeh et al. (2014) used the TOPSIS method to find the solution to urban and regional planning issues and evaluated site selection of new towns. The drawback of this method is the difficulty of weighting criteria and maintaining consistent judgment, especially with additional criteria (Behzadian et al., 2012). Yousefi et al. (2020) produced a multi-hazard risk map in a mountainous area using machine learning - such as a support vector machine, boosted regression tree, and generalized linear model - to find the best model for each hazard and then create an integrated multi-hazard map in ArcGIS by adding each hazard together. Not only the technical capabilities of multi-hazard maps have to be considered, but also the design of information provided in multi-hazard maps plays an important role for the end user's preferences (Dallo et al., 2020).

However, none of the studies have taken into consideration the natural abilities of humans to sense, adapt to, or modify their environment to avoid danger, which is the human perception of risk as individuals and the public perception of risk as communities or groups. Stakeholder involvement in the study will provide advantages to both researchers and stakeholders. The stakeholders will have opportunities to share their visions, needs, and knowledge regarding the hazards. They could also assist in reducing conflicts and increasing cooperation in the future. One of the most common multicriteria decision analysis (MCDA) methods is the analytic hierarchy process. The AHP (Saaty, 1990) uses a pairwise comparison to compare the relative significance among criteria designed from the stakeholders' judgment. In addition, Saaty and Vargas (2006) proposed the analytical network process (ANP), which is a general form of AHP, to evaluate dependant criteria. For example, Asadzadeh et al. (2015) used factor analysis with ANP (F'ANP) to construct a new set of parameters for a earthquake resilience indicator. Although AHP requires data to properly perform pairwise comparisons, it is not nearly as data intensive as MAUT (Kazakis et al., 2015; Stefanidis and Stathis, 2013). Among various multicriteria decision-making methods, the property of the AHP is in line with our study objective. Furthermore, AHP is recognized as a multicriteria method that is incorporated into GIS-based procedures for determining suitability (Parry et al., 2018; Prakash, 2003). Pourkhabbaz et al. (2014) used AHP in a GIS environment with the aim of choosing a suitable location for agricultural land use. Gigović et al. (2017) presented a reliable GIS-AHP methodology for hazard zone mapping of flood-prone areas in urban areas. From the results, the GIS-AHP hazard map provides good correlation between the high-hazard area of the map and historical flood 
events. Ramya and Devadas (2019) analyzed suitable locations for industrial development by using GIS, AHP, and TOPSIS. As a result, the most suitable industrial locations can be highlighted. Based on the research studies mentioned above, it could be concluded that the AHP is an effective and powerful tool for analyzing, structuring, and prioritizing complex problems considering expert judgment on various aspects. Therefore, the AHP is chosen for the studies of integrated multi-hazard mapping. The maps can detect subtle areas on the national scale, for which there are the limitation of available data. This modeling method combined several maps of hazards, for instance land use change, climate change, land slides, and flooding. Furthermore, the distribution pattern of hazards for both individual and integrated hazard maps is analyzed and discussed.

\section{Study area and data}

Lao PDR, or Laos, is situated in the middle of Southeast Asia. The country is landlocked, so it has no direct access to the sea and has common borders with China, Vietnam, Cambodia, Thailand, and Myanmar. The country is located in the center of the Indochinese peninsula, located between 14 and $23^{\circ} \mathrm{N}$ and 100 and $108^{\circ} \mathrm{E}$, with a total area of $236800 \mathrm{~km}^{2}$. The Mekong River flows through almost $1900 \mathrm{~km}$ of Lao territory from the north to the south, and it forms a natural border with Thailand over $800 \mathrm{~km}$. In addition, Lao PDR can be divided into three regions. These regions are determined by the Lao government, namely, the southern, central, and northern regions (Fig. S1 in the Supplement). Furthermore, Lao PDR is divided into 16 provinces and 1 capital, Vientiane (Fig. S2).

For this study, we used hydrological and meteorological datasets from Phrakonkham et al. (2019). The rainfall data were interpolated to a $1 \mathrm{~km} \times 1 \mathrm{~km}$ resolution using inverse distance weight (IDW). After that, the log-Pearson type III distribution was used to estimate the 100-year return period of extreme rainfall in Laos by using the annual maximum daily rainfall for each grid area. The hydrological data were used as input data for the rainfall-runoff model and probability-of-landslide model, as well as to calibrate the rainfall-runoff model. The land use of Laos is classified into forest, paddy field, agricultural area, water body, and urban.

In this study, a 100-year return period is used because most of the hazardous events have occurred due to the 100year return period of extreme rainfall. In addition to the rainfall data, daily maximum data are selected to analyze the rainfall intensity return period. The data were also used for bias correction between GCMs and observation data. In this study, representative concentration pathway (RCP) scenarios were used for future climate change projections because RCP scenario areas based on radiative forcing projections are allowed for policy change to be implemented. Seven GCMs - namely, CanESM2, CNRM-CM5, GFDL-
ESM2 M, MPI_ESM_LR, MRI-CGCM3, Miroc-ESM, and Miroc-ESM-CHEM (details about each GCM are shown in Table S1 in the Supplement) - were selected to create future scenarios of spatially distributed heavy rainfall. Rainfall data from the GCMs have different time resolutions; therefore, we converted all $3 \mathrm{~h}$ rainfall data to daily data by summing rainfall data from the same day. The rainfall data period was from 2006 to 2100 , and three RCPs were used, including $\mathrm{RCP} 2.6, \mathrm{RCP} 4.5$, and RCP8.5.

\section{Methodology}

\subsection{Outline of method}

In this study, the integrated hazard maps consist of five hazard maps: floods, land use changes, landslides, climate change impacts on floods, and climate change impacts on landslides.

\subsection{Flood hazards}

In this study, the model considers the meteorological dataset as input into an output hydrological dataset such as streamflow over a time period. A hydrological model is made of mathematical representations of key processes, such as precipitation, infiltration, and transfer into streams; the hydrological processes considered in this model are precipitation, infiltration, surface runoff, base water flow, and water balance in each layer. The model technically consists of a set of hydrological parameters describing the catchment properties and algorithms describing the physical processes. In this model, the catchment is divided into overland flow planes and channel segments. On the land, for each grid cell, two layers are considered in the vertical direction: the base water layer and the surface layer. For distributed system models, information on the geological and topographical characteristics of a river catchment is required to derive or measure the necessary parameters. The river basin characteristics were described by the set of data (elevation, flow direction, catchment area, and stream network) derived from the digital elevation model (DEM). More details about the performance and validation of the model are presented in Phrakonkham et al. (2019).

\subsection{Land use change hazards}

The scenario in which reduced forest and increased cropland areas are included was first used to assess the impacts of various land use scenarios on the flood hazard map in the present study area. To investigate the sensitive areas of the flood hazard map, this selection was chosen. Hence, the reduction in forest and all forest areas was considered and converted to the worst scenario and to cropland, respectively. One of the suitable geo-environmental factors of crop fields is slope (Ceballos-Silva and López-Blanco, 2003; Huynh, 2008). As 
shown by these studies, a slope of approximately 6-12\% will increase the growth of vegetation. Consequently, in the scenario designed first, the forest areas with slope angles less than and more than $12 \%$ were converted to cropland and remained unchanged. Second, based on the probability of increased population, an expansion of urban areas was created whose process was represented as moving from rural areas to urban areas.

\subsection{Landslide hazards}

Landslides are one of the most dangerous natural hazards, and they cause major damage to affected areas. To identify the locations of landslide hazard areas throughout Laos, a probabilistic model based on multiple logistic regression analysis was used. The model considers several important physical parameters, including hydraulic and geographical parameters. Among these, the hydrological parameter (i.e., hydraulic gradient) is the most important factor for determining the probability of a landslide (Kawagoe et al., 2010). The statistical approaches used for evaluation are indirect hazard mapping methodologies that involve a statistical determination based on a combination of variables that have identified land use occurrence (Ohlmacher and Davis, 2003; van Westen et al., 2006). In addition, probabilistic methods are used to determine the probability over a large area where numerous natural slopes exist. Hence, the hydraulic gradient is the main hydraulic parameter. Due to the lack of data in Laos, data from Thailand were used for this study on Laos (Kawagoe et al., 2010; Komori et al., 2018; Ono et al., 2011). In these studies, the probability of a landslide is derived as

$$
p=\frac{1}{1+\exp [-(-17.494+1179.25 \times \text { hydro } \times 0.0097 \times \text { relief })]},
$$

where $p$ is the probability, which is considered the hazard index of a landslide map, and "hydro" and "relief" are the hydraulic gradient and the relative relief, respectively.

Relative relief is defined as the elevation difference between the highest location and lowest location. Relief energy is an index that can show the complexity of geographical features considering the active development of landforms. Therefore, in this study, relief energy is defined as the elevation difference between the highest and the lowest elevation in each grid cell, and the relief energy for each $1 \mathrm{~km} \times 1 \mathrm{~km}$ resolution grid cell is estimated using DEM data.

The hydraulic gradient is a significant factor for the initiation of landslides. Changes in the hydraulic gradient in the slope area can lead to landslides. In this study, we use unsaturated infiltration analysis based on the Richards equation to find the change in hydraulic gradient (Kawagoe et al., 2010).

\subsection{Climate change hazards}

Climate change hazards are estimated as a future projection of climate change impacts on future floods and future landslide hazards. The prediction is obtained by the future projection of precipitation from the GCM dataset. In this study, the average precipitation from seven GCMs (Table S1) and three RCP scenarios were selected. Because most GCMs offer information at scales greater than a few hundred kilometers, statistical downscale bias correction quantile mapping was deployed (Eq. 2) to reduce the bias for precipitation output from the GCMs (Boé et al., 2007; Fajar Januriyadi et al., 2018; Fang et al., 2015; Lafon et al., 2013; Salem et al., 2018). First, the method for bias correction quantile mapping presented by Salem et al. (2018) is used. Then, the near- and far-future trends in rainfall are chosen as the average future precipitation data of the GCMs from 2010 to 2050 (2050s) and 2051 to 2099 (2100s). Additionally, the log-Pearson type III method was used to calculate the return period rainfall for all future rainfall patterns.

$z_{\text {cor }}=\mathrm{CDF}_{0}^{-1}\left(\mathrm{CDF}_{\mathrm{gcm}}\left(z_{\mathrm{gcm}}\right)\right)$,

where $z_{\text {cor }}$ is the precipitation after correcting the bias, $z_{\mathrm{gcm}}$ is the precipitation from GCMs before bias correction, $\mathrm{CDF}_{\mathrm{gcm}}$ is the cumulative distribution function (CDF) of $z_{\mathrm{gcm}}$, and $\mathrm{CDF}_{0}^{-1}$ is the inverse CDF of the observed rainfall.

\subsection{Hazard index}

\subsubsection{Flood hazard index classification}

We propose a hazard index, which is adapted from the relationship between velocity and flood depth (Priest et al., 2008). By considering the water depth of every grid in the flood map, we converted the value to a hazard index. The scenario was as follows: the water velocity from the flooded areas was low, and the depth can be transformed into a hazard index. The index is scaled from zero to one, with zero representing the lowest hazard and one representing the highest hazard. The hazard index was classified into four categories, i.e., small, medium, high, and very high hazards, which correspond to inundation depths of $0.0-0.3,0.31-0.6,0.61-2.0$, and more than $2.1 \mathrm{~m}$, respectively. Subsequently, we can find the relationship between flood depth and hazard index, as shown in Fig. 1, and the flood depth and hazard index curve can be derived.

\subsubsection{Landslide hazard index classification}

The probability of landslides (0-1) is used directly as the landslide hazard index (0-1). The landslide hazard map was classified using the natural-breaks method provided in the ArcGIS program. The natural-breaks method is a data classification method designed for determining the best arrangement in terms of representing the spatial distribution of the 

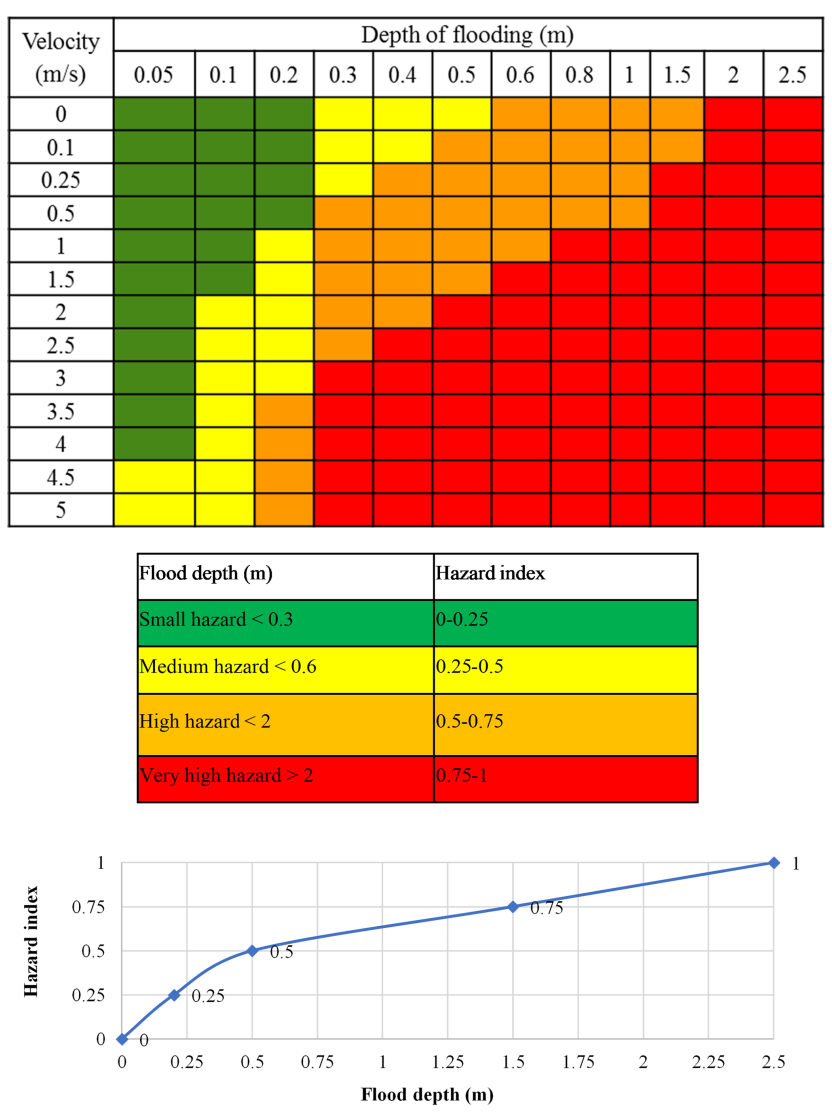

Figure 1. Flood depth-velocity relationship to the hazard index and curve.

data (Bednarik et al., 2010; Constantin et al., 2011; Erener and Düzgün, 2010; Falaschi et al., 2009; Mohan et al., 2011; Pourghasemi et al., 2012). In this study, we wanted to classify our data into 4 classes that are similar to flood hazard maps for convenience and for comparison to other hazard maps. Finally, the landslide hazard map is graded into four classes: low $(0-0.23)$, medium $(0.23-0.54)$, intermediate $(0.54-0.85)$, and high $(0.85-1)$.

\subsection{Analytical hierarchy process (AHP)}

The AHP method is a highly efficient method among multicriteria decision-making approaches. This method can prioritize multicriteria data using a pair comparison approach (Saaty, 1990). In a previous study (Phrakonkham et al., 2019), we conducted a questionnaire survey with expert officers overseeing various hazards and risks in Laos. In the survey questionnaires, experts were asked to provide their judgments on three hazards: floods, land use changes, and climate change impacts on floods. In the present study, however, five hazards are asked in the questionnaires. We have five criteria, which include floods, land use changes, landslides, climate change impacts on floods, and climate change impacts on landslides; thus, the matrix is 5 by 5 , and the diagonal elements are equal to 1 . The value of each row of pairwise comparisons is determined based on expert judgments.

To obtain the criteria's relative priority value expert judgments are required. We designed and conducted a questionnaire at the Ministry of Natural Resource and Environment of Laos because most of the officers who work in this ministry have knowledge of flood hazards, climate changes, and land use impacts in Laos (Table S2). All the experts and those who had experience in the field of our concerned hazards were asked to complete a questionnaire. Approximately $41 \mathrm{sam}$ ples were collected from all the expert officers at the Ministry of Natural Resource and Environment. By using Eq. (3), we obtained a value for each pairwise comparison from each row of the questionnaires.

$\operatorname{Rel}_{j}=\sqrt[m]{\frac{\prod_{i=1}^{m} A_{m, j}}{\prod_{i=1}^{m} B_{m, j}}}$,

where $\operatorname{Rel}_{j}$ is the relative importance of the pairwise criteria in the $j$ th row from the questionnaire (for example, row $j=1$ st represents the pairwise comparison between flood and land use change) and $m$ is the number of samples (in this study, $m=41$ ).

According to Saaty (1990), the weight $\left(\boldsymbol{w}_{i}\right)$ is the normalized eigenvector of the matrix $\left(\mathbf{D}_{i, k}\right)$ associated with the largest eigenvalue $\lambda_{\max }$ of the matrix $\left(\mathbf{D}_{i, k}\right) . \boldsymbol{w}_{i}(i=$ $1,2, \ldots, 5)$ is the weight of each hazard corresponding to the hazard from the $i$ th row of Table 1 ; for example, $w_{1}(i=$ $1)$ is the weight of the flood hazard $\left(\boldsymbol{w}_{1}=\boldsymbol{w}_{\text {flood }}\right)$ according to Table $1\left(\boldsymbol{w}_{2}=\boldsymbol{w}_{\text {land use change }}, \boldsymbol{w}_{3}=\boldsymbol{w}_{\text {landslide }}, \boldsymbol{w}_{4}=\right.$

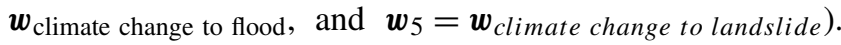
The weights for the pairwise comparison matrix are presented in Table 1. After we obtain the weights of each hazard, its consistency must be evaluated if the consistency ratio is less than 0.1. More details about consistency can be found in Saaty (1990). In this study, the calculated consistency ratio was 0.03 , indicating that the results from the questionnaire were consistent.

\subsection{AHP-based hazard map}

To integrate the above flooding, land use, landslides, climate change leading to floods, and climate change leading to landslides hazard maps, the AHP-based hazard index is used. This index is also deployed to assimilate the weight of each criterion used to assign its role in the final map. Each grid must therefore be evaluated based on all criteria. The AHPbased hazard index can be derived as follows: 
Table 1. AHP pairwise comparison matrix $\left(\mathbf{D}_{i, k}\right)$ with the weight of each criterion.

\begin{tabular}{|c|c|c|c|c|c|c|}
\hline Option B $(k) /$ option A $(i)$ & Flood & $\begin{array}{r}\text { Land } \\
\text { use } \\
\text { change }\end{array}$ & Landslide & $\begin{array}{l}\text { Climate } \\
\text { change } \\
\text { leading to } \\
\text { floods }\end{array}$ & $\begin{array}{r}\text { Climate } \\
\text { change } \\
\text { leading to } \\
\text { landslides }\end{array}$ & $\begin{array}{r}\text { Weight } \\
\qquad\left(w_{i}\right)\end{array}$ \\
\hline Flood & 1.00 & 4.20 & 7.10 & 0.71 & 4.10 & 0.33 \\
\hline Land use change & 0.24 & 1.00 & 3.60 & 0.18 & 1.60 & 0.11 \\
\hline Landslide & 0.14 & 0.28 & 1.00 & 0.17 & 0.34 & 0.045 \\
\hline Climate change leading to floods & 1.4 & 5.4 & 5.7 & 1.00 & 5.50 & 0.42 \\
\hline Climate change leading to landslides & 0.24 & 0.63 & 2.9 & 0.18 & 1.00 & 0.09 \\
\hline Sum & 3.02 & 11.50 & 20.30 & 2.26 & 12.54 & 1 \\
\hline
\end{tabular}

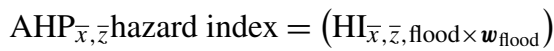

$$
\begin{aligned}
& +\left(\mathrm{HI}_{\bar{x}, \bar{z}, \text { land use change } \times \boldsymbol{w}_{\text {land }} \text { use change }}\right) \\
& +\left(\mathrm{HI}_{\bar{x}, \bar{z}, \text { land slide }} \times \boldsymbol{w}_{\text {land slide }}\right) \\
& +\left(\mathrm{HI}_{\bar{x}}, \bar{z}, \text { climate change to flood } \times \boldsymbol{w}_{\text {climate change to flood }}\right) \\
& +\left(\mathrm{HI}_{\bar{x}, \bar{z} \text {, climate change to landslide }} \times \boldsymbol{w}_{\text {climate change to landslide }}\right) \text {, }
\end{aligned}
$$

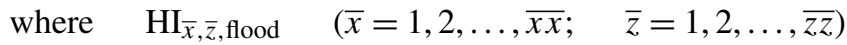
is a hazard index value from the flood hazard map;

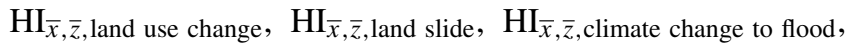
and $\mathrm{HI}_{\bar{x}}, \bar{z}$,climate change to landslide are hazard index values from land use change, landslides, climate change leading to floods, and climate change leading to landslides hazard maps, respectively; $\bar{x}$ is a vertical coordination grid on the map; and $\bar{z}$ is a horizontal coordination grid on the map. Every hazard map (flood, landslide, and so on) has an equal number of horizontal and vertical grids; $\overline{x x}$ is the number of vertical grids, and $\overline{z z}$ is the number of horizontal grids from the hazard map. For the classification of integrated hazard maps, we apply the natural-breaks method from Sect. 4.6.2 for the classification because the method can determine the best arrangement of values into different classes. The integrated hazard map was classified into four hazard areas, corresponding to low-hazard (0-0.21), medium-hazard (0.22-0.43), high-hazard (0.44-0.68), and very high hazard $(0.69-1.0)$ areas.

\section{Results}

\subsection{Flood hazard map}

A distributed hydrological model was used to simulate a flood hazard map for the whole country. We considered the greatest water depth in every grid cell, which was determined by contributing factors during the simulation, and these factors included the 100-year return periods of rainfall, land types, soil hydrologic characteristics, and elevation. The results are shown in Fig. 2, where we can see the potential flood hazard areas. The results reveal that low-hazard areas

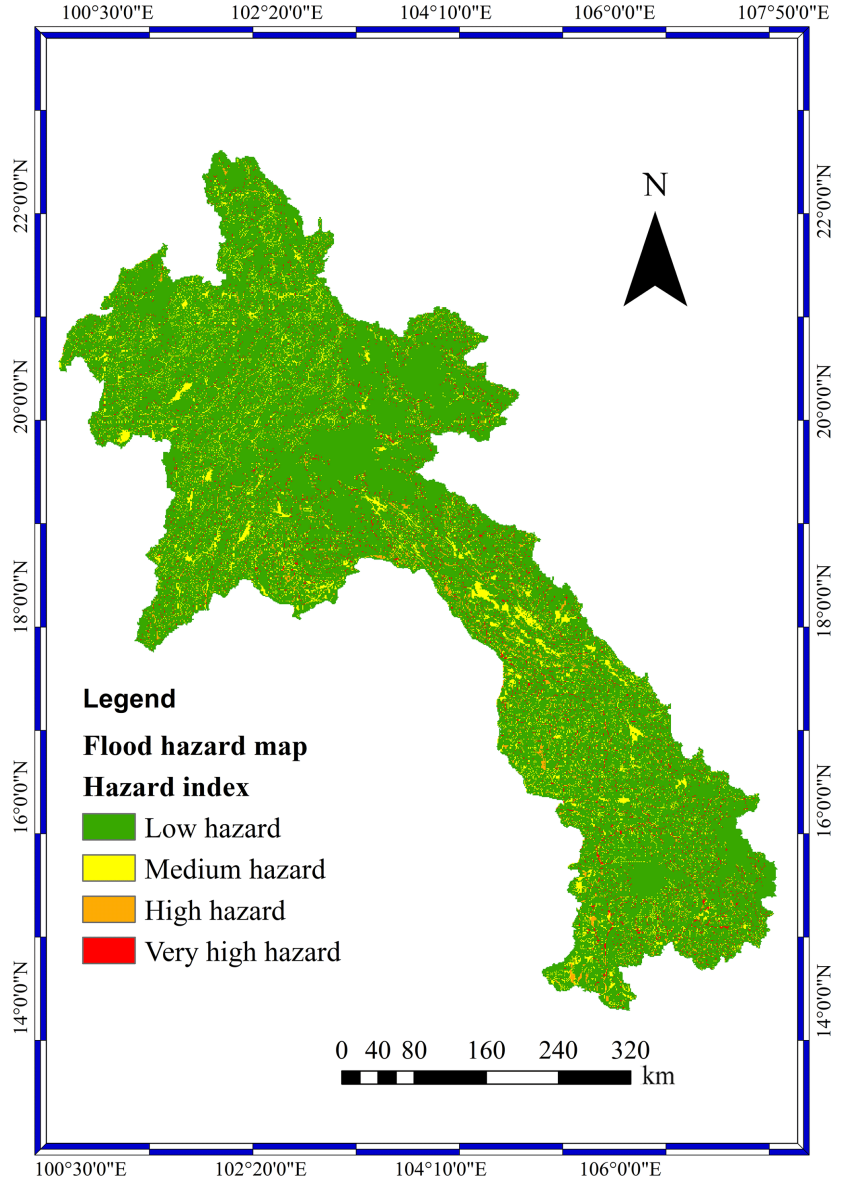

Figure 2. Flood hazard map.

cover $78.44 \%$ of the total area, medium-hazard areas cover $12.64 \%$, and high- and very high hazard areas cover 6.14 and $2.78 \%$, respectively.

\subsection{Landslide hazard map}

According to the results shown in Fig. 3, most of the hazard areas are located around the central to southern parts of Laos. 


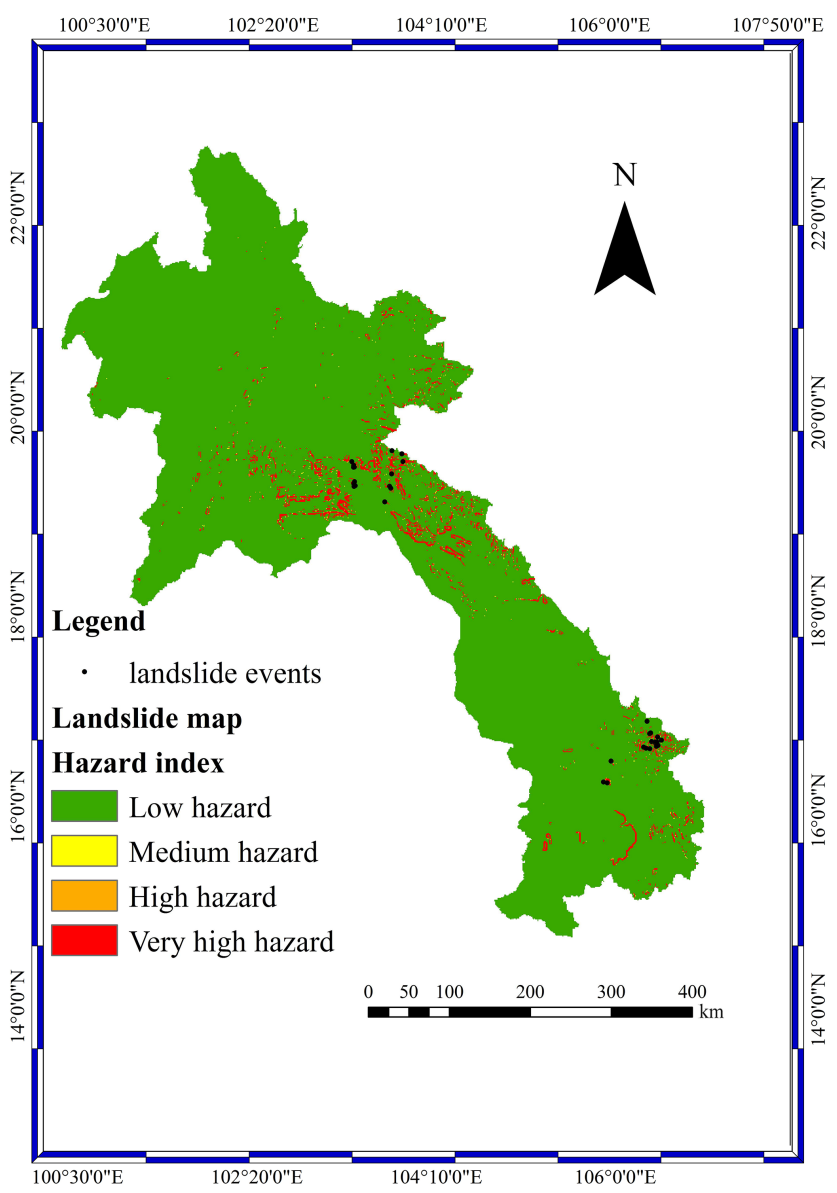

Figure 3. Landslide hazard map and historical landslide events.

In addition, the records of landslide events in Laos show that those landslide events are closely related to the probability of exceeding values of rainfall. The results reveal that the lowhazard areas cover $92.67 \%$, the medium-hazard areas cover $1.83 \%$, the high-hazard areas cover $1.21 \%$, and the very high hazard areas cover $4.28 \%$ of the total area. The landslide hazard map was validated by comparing the landslide hazard map results with historical landslide events in Lao PDR, in which those events occurred with the extreme rainfall of a 100-year return period. Approximately 33 landslide events (Fig. 3) were used for comparison with the landslide hazard map results. From the results, 22 events $(66.67 \%)$ were located in very high hazard areas, 8 events $(24.24 \%)$ were located in high-hazard areas, and 3 events $(9.09 \%)$ were located in low-hazard areas. The landslide hazard map from our simulation corresponds to the historical landslide events in the country. These results confirm that the landslide model and landslide hazard map can predict the occurrence of landslides in Lao PDR.

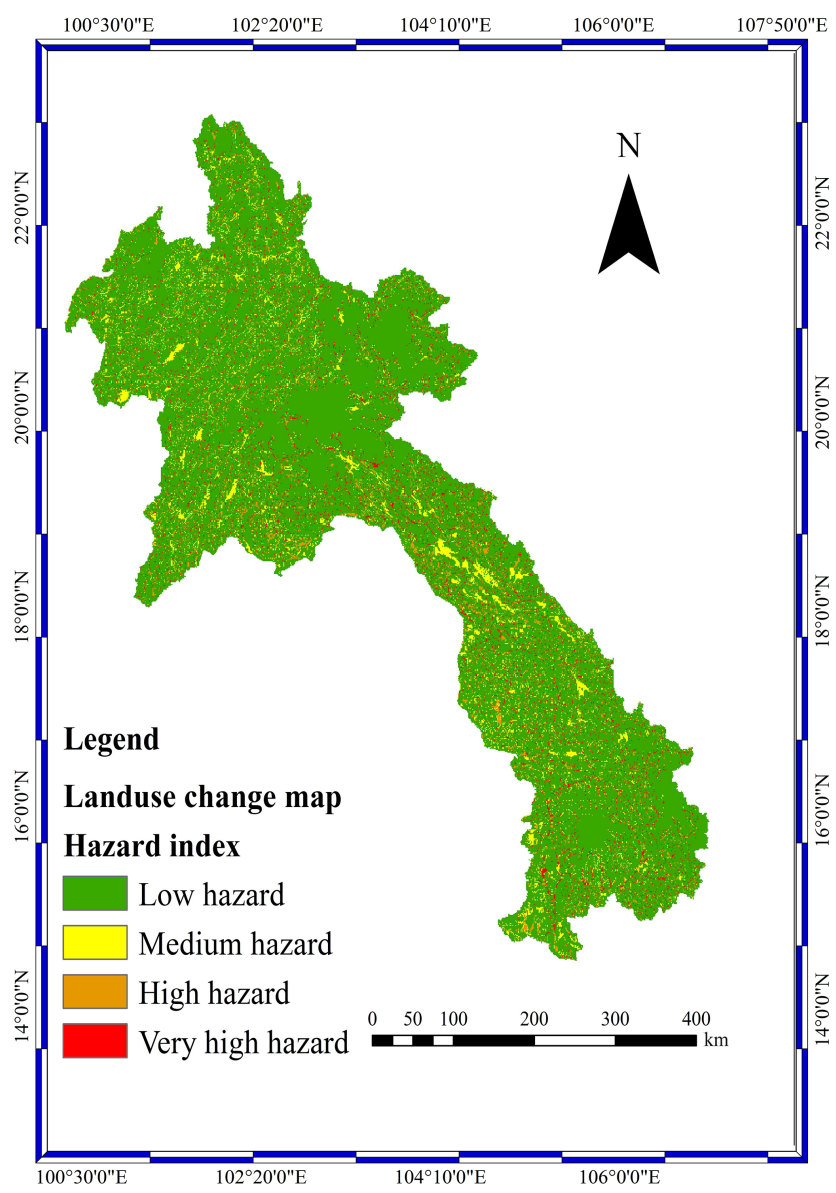

Figure 4. Land use change hazard map.

\subsection{Land use change hazard map}

The results in Fig. 4 show the overall impact of the hazard areas, which are growing significantly; this is mostly because of the loss of forest area, which slows the rainfall runoff. Without forest area, all rainfall runoff runs directly downstream without storage or other factors to slow it down. Therefore, the hazard areas downstream are expanding. The total area of land use change impacts on floods was divided into $77.08,12.68,6.94$, and $3.3 \%$ of low-, medium-, high-, and very high hazard areas, respectively.

\subsection{Climate change hazard map}

\subsubsection{Climate change impact on floods hazard map}

Developing countries in tropical regions are highly susceptible to floods. These regions already have high levels of precipitation, and the hydrologic cycle is significantly interlinked and sensitive to the weather. Future scenarios of flood hazard maps for the near and far future under three scenarios have been generated (Fig. S3). The percentage of very high hazard areas for the near future increased from $3.71 \%$ under 
RCP2.6 to $4.05 \%$ under the RCP8.5 scenario; additionally, for the far future, the percentage of very high hazard areas increased from $4 \%$ under the RCP2.6 scenario to $4.88 \%$ under RCP8.5. In the climate change hazard map with respect to the change in the flood hazard map, under all scenarios, the maximum high-hazard areas were $0.33 \%$ in urban areas, $88.77 \%$ in forest areas, $2 \%$ in paddy field areas, and $9.0 \%$ in agricultural areas. It was also seen that the very high hazard areas represented $0.35,90.09,1.8$, and $7.77 \%$ of the urban, forest, paddy field, and agricultural areas, respectively.

\subsubsection{Climate change impact on landslides hazard map}

Future landslides under the three scenarios and two time periods were simulated (Fig. S4). The percentage of very high hazard areas for the near future increased from $3.71 \%$ under RCP2.6 to $4.05 \%$ under the RCP8.5 scenario; additionally, for the far future, the percentage of very high hazard areas increased from $4 \%$ under the RCP2.6 scenario to $4.88 \%$ under RCP8.5. In the climate change hazard map with respect to the change in the landslide hazard map, under all scenarios, the maximum high-hazard areas were $0.13 \%$ in urban areas, $88.98 \%$ in forest areas, $0.84 \%$ in paddy field areas, and $10.05 \%$ in agricultural areas. It was also seen that the very high hazard areas represented $0.15,90.31,0.77$, and $8.77 \%$ of the urban, forest, paddy field, and agricultural areas, respectively.

\subsection{Integrated hazard maps}

The main objective of this chapter is to integrate the five existing hazard maps (floods, landslides, land use changes, climate change impacts on floods, and climate change impacts on landslides). Phrakonkham et al. (2019) proposed the AHP-based method for integrated multi-hazard maps in Lao PDR, namely, flood, land use change, and climate change leading to flood hazard maps. Based on the results, the AHPbased integrated hazard map can show potential hazard areas at the country scale. In this study, six integrated hazard maps under the three RCP scenarios (RCP2.6, RCP4.5, and RCP8.5) and the two time periods - near-future (2050s) and far-future (2100s) - were produced using the AHP method (Fig. S5). The integrated hazard maps were categorized using the natural-breaks method of classification (Tate et al., 2010). It was noticeable that the total amount of very high hazard areas increased in response to the RCP scenarios. In the near future, the percentage of very high hazard areas increased from $3.20 \%$ under RCP2.6 to $3.3 \%$ under RCP8.5. Similar results are shown for the far future; the proportion of high-hazard areas increases from $3.23 \%$ under RCP2.6 to $3.71 \%$ under RCP8.5.

To validate the performance of the integrated hazard maps, 30 historical flood events and 33 historical landslide events were compared to the integrated hazard maps (Fig. 5). According to the results, for historical flood events, 2 events

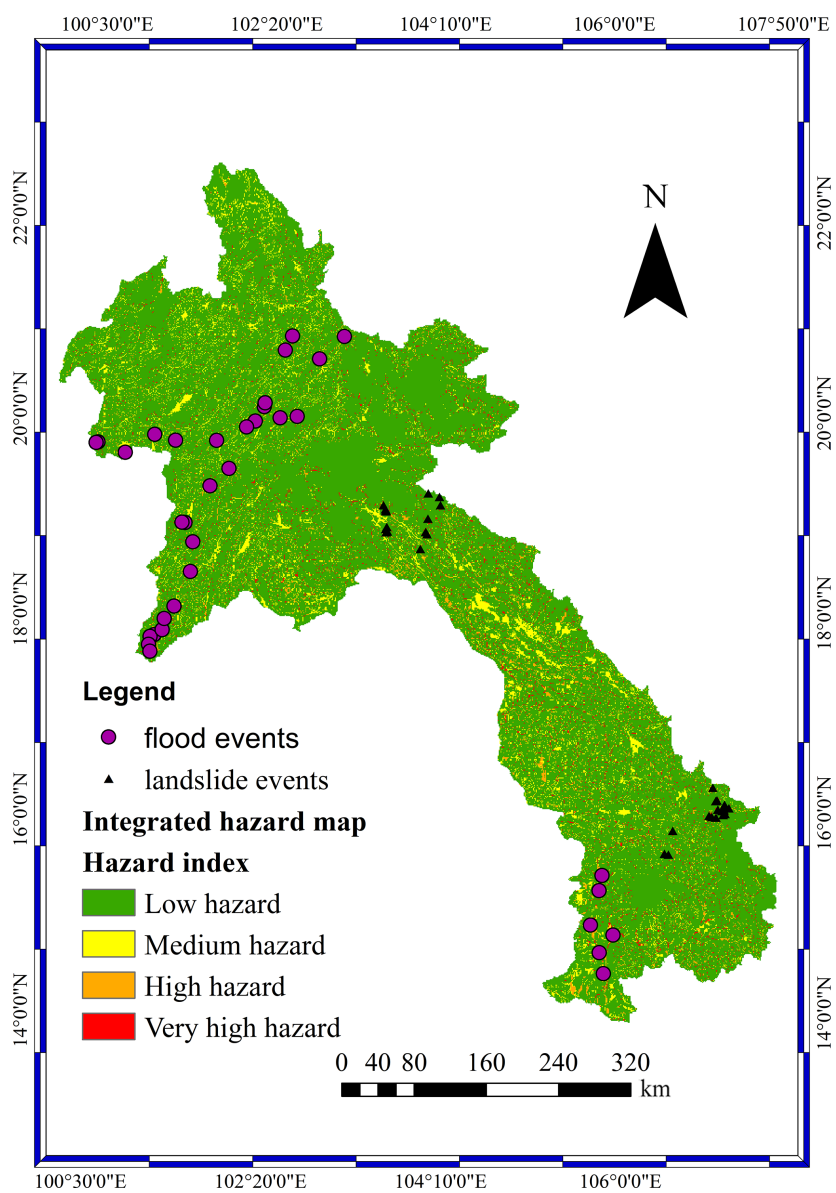

Figure 5. Comparison of historical flood and landslide events to the integrated hazard map of scenario RCP2.6 during the near future.

(7\%) were located in low-hazard areas, 3 events $(10 \%)$ were located in medium-hazard areas, $14(46 \%)$ events were located in high-hazard areas, and 11 (37\%) events were located in very high hazard areas. For historical landslide events, $7(21 \%)$ events were located in low-hazard areas, $8(24 \%)$ events were located in medium-hazard areas, $11(33 \%)$ events were located in high-hazard areas, and $7(21 \%)$ events were located in very high hazard areas. The majority of historical landslide $(54 \%)$ and flood $(83 \%)$ events were located in high- and very high hazard areas. Hence, the reliability of the integrated hazard map was confirmed.

\section{Discussion}

Flood hazard maps have demonstrated the distribution of hazard areas across the study area. Notably, most of the hazard area distributions were located in the central and southern regions of Lao PDR. Vientiane is located in the central region, and little of the area in the Vientiane capital area is impacted by flood hazards. Based on the results, a highhazard area is visible around the central-southern region of 
Lao PDR. High- and very high hazard areas in each province were divided by the whole country area to obtain their proportions of hazard areas (Table S3). For very high hazard areas, Bolikhamsai $(0.27 \%)$ (Fig. S6), Savannakhet $(0.27 \%$ ) (Fig. S7), and Vientiane provinces $(0.26 \%)$ (Fig. S8) have the highest percentage of very high hazard areas. For the capital of Lao PDR, only $0.08 \%$ of total high-hazard areas and $0.04 \%$ of total very high hazard areas are located in Vientiane (Fig. S9), and the capital has the lowest percentage of total high- and very high hazard areas among all the provinces. Champasak is one of the large provinces and developed areas of Lao PDR. Approximately $0.45 \%$ of the total high-hazard area and $0.18 \%$ of the total very high hazard area are located in Champasak Province (Fig. S10). Compared to Vientiane, Champasak has higher proportions of both high- and very high hazard areas.

The landslide hazard map shows the distribution of potential hazard areas from landslides around mountains in the central and southern regions. According to the results, most of the landslide hazard areas are located in forest areas, followed by agricultural areas and paddy fields. Most agricultural and paddy field areas belong to ethnic groups that have their livelihoods near mountainous areas. In Lao PDR, for many ethnic groups living in mountainous areas, the main source of income is agricultural production. Compared to other provinces of Lao PDR, Xiangkhouang, Bolikhamsai, and Vientiane have high mountainous areas; for instance, Bolikhamsai has the highest percentage of highhazard areas $(0.48 \%)$ (Table $\mathrm{S} 4)$. Very high hazard areas comprise approximately $0.6 \%$ of Xiangkhouang (Fig. S11), approximately $2.31 \%$ of Bolikhamsai (Fig. S12), and $0.92 \%$ of Vientiane (Fig. S13). Xiangkhouang has approximately $0.6 \%$ (Fig. S11), Bolikhamsai has approximately $2.31 \%$ (Fig. S12), and Vientiane has $0.92 \%$ of very high hazard areas (Fig. S13). These provinces should be given priority for developing mitigation and countermeasures. Most of the mountainous areas in these provinces provide livelihoods for different ethnic groups. Therefore, most landslide hazards occurring in these areas will have a direct impact on agriculture and the properties of ethnic groups.

The land use change hazard map shows a distribution similar to that of the flood hazard map but with a higher magnitude. Overall, the high-hazard areas and very high hazard areas increase when comparing the land use change hazard map to the flood hazard map (Tables S5 and S6). The highhazard areas of the land use change hazard map increase by approximately $13 \%$, and the very high hazard areas increase by approximately $19 \%$, compared to the high- and very high hazard areas of the current flood hazard map. Similar to the flood hazard map, Savannakhet Province has the highest percentage of high- $(0.96 \%)$ and very high hazard areas $(0.3 \%)$ (Fig. S14). However, compared to the flood hazard map, the high- and very high hazard areas of Savannakhet Province slightly increased. The Vientiane capital area had a greater impact than Champasak Province. The very high hazard area in Vientiane increases by approximately $82 \%$, and the highhazard area increases by $60 \%$. It is indicated that Vientiane is more highly influenced than Champasak Province by land use change. It is indicated that land use change has a significant influence on the magnitude of flooding area. The results correspond to Huntington (2006), who found that land use change from human alterations, such as the conversion of forest area to agricultural area or the expansion of urban area, will lead to an increase in flood hazard area.

Climate change impacts on flood hazard maps are represented by the flood hazard map under future climate conditions with three scenarios (RCP2.6, RCP4.5, and RCP8.5) and two time periods (near future and far future). The flood hazard area under the influence of future rainfall conditions shows an increase across the country. By considering the near-future period (Fig. S15), for instance, Luang Namtha Province has the highest increase $(23 \%)$ of very high hazard areas (Fig. S16) when comparing the flood hazard map under scenario RCP2.6 to that under RCP4.5 (Table S7). In Bolikhamsai Province, the highest increase (5\%) (Fig. S17) of very high hazard areas was observed when comparing the flood hazard maps under scenarios RCP4.5 and RCP8.5 (Table S8). For the far-future period, the total percentage of very high hazard area increases from $4 \%$ under the RCP2.6 scenario to $4.22 \%$ under the RCP4.5 scenario, and it increases to $4.88 \%$ under the RCP8.5 scenario (Fig. S18). In many provinces, the climate change impacts on flood hazard maps in the near and far future have continuously increasing very high hazard areas from RCP2.6 to RCP8.5 (Tables S9 and S10). In addition, the future rainfall projections under the RCP2.6, RCP4.5, and RCP8.5 scenarios match the increases in the very high flood hazard areas from the RCP4.5 to RCP2.6 and RCP8.5 to RCP4.5 scenarios (Figs. S19 and S20). Overall, the amount of rainfall increases, particularly in Khammouan, Bolikhamsai, and Attapeu provinces, which is in line with the results.

Climate change impacts on the landslide hazard map are represented by the landslide hazard map under future climate conditions with three scenarios and two time periods. By considering the near-future period (Fig. S21), the total percentage of very high hazard area of $4.85 \%$ under the RCP2.6 scenario increases to $4.92 \%$ under the RCP4.5 scenario and increases to $4.96 \%$ under the RCP8.5 scenario. The climate change impacts on landslide hazard maps in the near future in many provinces have continuously increasing very high hazard areas from RCP2.6 to RCP8.5 (Tables S11 and S12). For the far future (Fig. S22), when the increase in the very high hazard area between future landslides under RCP2.6 and future landslides under RCP4.5 is compared, Bolikhamsai Province has the highest increase from $2.93 \%$ under the RCP2.6 scenario to $3.2 \%$ under the RCP4.5 scenario (Table S13). Bolikhamsai Province has the highest increase $(5 \%)$ in the very high hazard area when comparing the landslide hazard maps under the RCP4.5 and RCP8.5 scenarios (Table S14). In most of the provinces, the very 
Table 2. Percentage of very high hazard area from the integrated hazard map in each province and the percentage of increase between the RCP4.5 and RCP2.6 scenarios during the near future.

\begin{tabular}{|c|c|c|c|}
\hline Province name & $\begin{array}{r}\text { Percentage } \\
\text { of very } \\
\text { high hazard } \\
\text { area under } \\
\text { RCP2.6 }\end{array}$ & $\begin{array}{l}\text { Percentage } \\
\text { of very } \\
\text { high hazard } \\
\text { area under } \\
\text { RCP4.5 }\end{array}$ & $\begin{array}{c}\text { Percentage } \\
\text { increase } \\
\text { in very } \\
\text { high hazard } \\
\text { area between } \\
\text { RCP4.5 and } 2.6\end{array}$ \\
\hline Attapeu & $0.23 \%$ & $0.23 \%$ & $0.31 \%$ \\
\hline Bokeo & $0.07 \%$ & $0.07 \%$ & $0.64 \%$ \\
\hline Bolikhamsai & $0.32 \%$ & $0.33 \%$ & $3.05 \%$ \\
\hline Champasak & $0.21 \%$ & $0.22 \%$ & $0.28 \%$ \\
\hline Houaphan & $0.22 \%$ & $0.22 \%$ & $0.20 \%$ \\
\hline Khammouan & $0.32 \%$ & $0.32 \%$ & $0.94 \%$ \\
\hline Luang Namtha & $0.08 \%$ & $0.08 \%$ & $4.36 \%$ \\
\hline Luang Prabang & $0.19 \%$ & $0.20 \%$ & $4.21 \%$ \\
\hline Oudomxai & $0.12 \%$ & $0.12 \%$ & $3.47 \%$ \\
\hline Phongsaly & $0.11 \%$ & $0.11 \%$ & $1.03 \%$ \\
\hline Salavan & $0.13 \%$ & $0.13 \%$ & $1.18 \%$ \\
\hline Savannakhet & $0.36 \%$ & $0.38 \%$ & $4.69 \%$ \\
\hline Vientiane Province & $0.30 \%$ & $0.31 \%$ & $2.86 \%$ \\
\hline Vientiane Prefecture & $0.04 \%$ & $0.04 \%$ & $0.34 \%$ \\
\hline Xaignabouli & $0.19 \%$ & $0.20 \%$ & $1.80 \%$ \\
\hline Xekong & $0.14 \%$ & $0.14 \%$ & $1.30 \%$ \\
\hline Xiangkhouang & $0.17 \%$ & $0.17 \%$ & $1.56 \%$ \\
\hline $\begin{array}{l}\text { Total percentage of very } \\
\text { high hazard area } \\
\text { across the country }\end{array}$ & $3.2 \%$ & $3.27 \%$ & \\
\hline
\end{tabular}

high hazard area from climate change impacts on landslide hazard maps increases continually in the far future from RCP2.6 to RCP8.5, for example, in Bolikhamsai Province (Fig. S23). Based on the results, the increase in rainfall intensity (Figs. S19 and S20) due to climate change influences the increase in flood and landslide hazard areas. Many studies in the Mekong Delta (Dinh et al., 2012; Lauri et al., 2012) have revealed that climate change has impacts on rainfall intensity, which leads to increases in flood and landslide frequencies. Therefore, these results are in line with those of other research studies.

The integrated maps consist of flooding, land use change, landslide, and climate change hazards. The maps are developed using the AHP to perform the integration. The integrated hazard map consists of six maps under three RCP scenarios and two time periods. Figure $6 \mathrm{~d}$ shows the area of the hazard index increase when comparing the integrated hazard map for the near future under the RCP2.6 and RCP4.5 scenarios. Savannakhet Province is highly influenced by climate change (Fig. S24). The percentage of the very high hazard area from the integrated hazard map increases by approximately $4.69 \%$ when comparing the RCP 2.6 and RCP4.5 scenarios (Table 2). Figure 6e shows the area of the hazard index increase when comparing the RCP8.5 and RCP4.5 scenarios. Among others, Khammouan (Fig. S25), Vientiane (Fig. S26), Savannakhet (Fig. S27), and Bolikhamsai provinces (Fig. S28) have higher increases in very high haz-
Table 3. Percentage of very high hazard area from the integrated hazard map in each province and the percentage of increase between the RCP8.5 and RCP4.5 scenarios during the near future.

\begin{tabular}{|c|c|c|c|}
\hline Province name & $\begin{array}{l}\text { Percentage } \\
\text { of very } \\
\text { high hazard } \\
\text { area under } \\
\text { RCP4.5 }\end{array}$ & $\begin{array}{r}\text { Percentage } \\
\text { of very } \\
\text { high hazard } \\
\text { area under } \\
\text { RCP8.5 }\end{array}$ & $\begin{array}{c}\text { Percentage } \\
\text { increase } \\
\text { in very } \\
\text { high hazard } \\
\text { area between } \\
\text { RCP8.5 and } 4.5\end{array}$ \\
\hline Attapeu & $0.23 \%$ & $0.23 \%$ & $0.98 \%$ \\
\hline Bokeo & $0.07 \%$ & $0.07 \%$ & $0.29 \%$ \\
\hline Bolikhamsai & $0.33 \%$ & $0.34 \%$ & $1.43 \%$ \\
\hline Champasak & $0.22 \%$ & $0.22 \%$ & $0.92 \%$ \\
\hline Houaphan & $0.22 \%$ & $0.22 \%$ & $0.95 \%$ \\
\hline Khammouan & $0.32 \%$ & $0.32 \%$ & $1.37 \%$ \\
\hline Luang Namtha & $0.08 \%$ & $0.08 \%$ & $0.34 \%$ \\
\hline Luang Prabang & $0.20 \%$ & $0.20 \%$ & $0.87 \%$ \\
\hline Oudomxai & $0.12 \%$ & $0.12 \%$ & $0.52 \%$ \\
\hline Phongsaly & $0.11 \%$ & $0.11 \%$ & $0.48 \%$ \\
\hline Salavan & $0.13 \%$ & $0.13 \%$ & $0.54 \%$ \\
\hline Savannakhet & $0.38 \%$ & $0.39 \%$ & $1.62 \%$ \\
\hline Vientiane Province & $0.31 \%$ & $0.32 \%$ & $1.34 \%$ \\
\hline Vientiane Prefecture & $0.04 \%$ & $0.04 \%$ & $0.16 \%$ \\
\hline Xaignabouli & $0.20 \%$ & $0.20 \%$ & $0.84 \%$ \\
\hline Xekong & $0.14 \%$ & $0.14 \%$ & $0.60 \%$ \\
\hline Xiangkhouang & $0.17 \%$ & $0.17 \%$ & $0.72 \%$ \\
\hline $\begin{array}{l}\text { Total percentage of very } \\
\text { high hazard area } \\
\text { across the country }\end{array}$ & $3.27 \%$ & $3.3 \%$ & \\
\hline
\end{tabular}

ard areas when comparing integrated hazard maps under the RCP4.5 and RCP8.5 scenarios (Table 3). For the far-future period, Fig. $7 \mathrm{~d}$ shows the area of the hazard index increase when comparing the RCP4.5 and RCP2.6 scenarios. Comparing the increase in the very high hazard area in the integrated hazard map under the RCP2.6 and RCP4.5 scenarios, Khammouan Province has the highest increase $(16.45 \%)$ (Table 4). Figure 7e shows the area of the hazard index increase when comparing the RCP8.5 and RCP4.5 scenarios. Khammouan Province has the highest increase in the very high hazard area (12.47\%) when comparing the flood hazard maps under the RCP2.6 and RCP4.5 scenarios (Table 5). The increase in the very high hazard areas for the integrated hazard map is similar to that for the rainfall patterns from the RCP2.6 to RCP4.5 and RCP4.5 to RCP8.5 scenarios with near- and far-future periods (Figs. S19 and S20). The southern region has the highest increase in very high hazard areas, particularly Bolikhamsai, Khammouan, and Savannakhet provinces. Special attention must be paid to these provinces, particularly to countermeasures and adaptation planning, to reduce the potential risk. The produced integrated hazard map identified suitable areas for development in the northern part of Laos, which had the greatest amount of low-hazard areas ( $42 \%$ ). It is too challenging for our study area to obtain observed data. It is also difficult to access data sources. Therefore, multiple data sources were used in this study. Data from different sources have different format, 
Table 4. Percentage of very high hazard area from the integrated hazard map in each province and the percentage of increase between the RCP4.5 and RCP2.6 scenarios during the far future.

\begin{tabular}{|c|c|c|c|}
\hline Province name & $\begin{array}{l}\text { Percentage } \\
\text { of very } \\
\text { high hazard } \\
\text { area under } \\
\text { RCP2.6 }\end{array}$ & $\begin{array}{c}\text { Percentage } \\
\text { of very } \\
\text { high hazard } \\
\text { area under } \\
\text { RCP4.5 }\end{array}$ & $\begin{array}{r}\text { Percentage } \\
\text { increase } \\
\text { in very } \\
\text { high hazard } \\
\text { area between } \\
\text { RCP4.5 and } 2.6\end{array}$ \\
\hline Attapeu & $0.23 \%$ & $0.25 \%$ & $8.67 \%$ \\
\hline Bokeo & $0.07 \%$ & $0.07 \%$ & $2.58 \%$ \\
\hline Bolikhamsai & $0.33 \%$ & $0.37 \%$ & $12.39 \%$ \\
\hline Champasak & $0.22 \%$ & $0.23 \%$ & $8.16 \%$ \\
\hline Houaphan & $0.22 \%$ & $0.24 \%$ & $8.44 \%$ \\
\hline Khammouan & $0.32 \%$ & $0.37 \%$ & $16.45 \%$ \\
\hline Luang Namtha & $0.08 \%$ & $0.08 \%$ & $2.90 \%$ \\
\hline Luang Prabang & $0.20 \%$ & $0.21 \%$ & $7.41 \%$ \\
\hline Oudomxai & $0.12 \%$ & $0.12 \%$ & $4.48 \%$ \\
\hline Phongsaly & $0.11 \%$ & $0.12 \%$ & $4.17 \%$ \\
\hline Salavan & $0.13 \%$ & $0.13 \%$ & $4.77 \%$ \\
\hline Savannakhet & $0.37 \%$ & $0.41 \%$ & $11.35 \%$ \\
\hline Vientiane Province & $0.31 \%$ & $0.34 \%$ & $11.62 \%$ \\
\hline Vientiane Prefecture & $0.04 \%$ & $0.04 \%$ & $1.37 \%$ \\
\hline Xaignabouli & $0.19 \%$ & $0.21 \%$ & $7.28 \%$ \\
\hline Xekong & $0.14 \%$ & $0.15 \%$ & $5.26 \%$ \\
\hline Xiangkhouang & $0.17 \%$ & $0.18 \%$ & $6.31 \%$ \\
\hline $\begin{array}{l}\text { Total percentage of very } \\
\text { high hazard area } \\
\text { across the country }\end{array}$ & $3.23 \%$ & $3.52 \%$ & \\
\hline
\end{tabular}

structure, and type and should be transformed to the same format, structure, and type with the same quality.

Dankers and Feyen (2008) have assessed the influent of climate change to future flood hazard in Europe. They have concluded that by the end of this century discharge level from many rivers in European will increase in both magnitude and frequency. However, a few rivers will have a decrease in discharge levels, such as rivers in the northeast Europe region. Mirza (2011) indicated that it is highly likely that climate change will influence monsoon precipitation and lead to an increase in the frequency, magnitude, and extent of the flood hazard in South Asia, such as Bangladesh, India, and Pakistan. Also, the damage to agriculture, human life, and infrastructure will increase in the future. Bouwer et al. (2010) investigated the change of flood risk due to climate change and its damage cost. Change of future precipitation and socioeconomic change such as land use change and increase of value assets were considered for assessing the damage cost from future flood risk. They concluded that the climate change will increase the damage cost from flood risk by around 35$170 \%$ by 2040 in the Netherlands. Sidle and Ochiai (2006) evaluated climate change variables that will trigger landslide hazard. They concluded that increasing seasonal air temperature and precipitation were the most interrelated climate variables that will trigger landslide hazard. Ciabatta et al. (2016) investigated the impact of climate change on the occurrence of landslides in Italy by using the PRESSA model developed
Table 5. Percentage of very high hazard area from the integrated hazard map in each province and the percentage of increase between the RCP8.5 and RCP4.5 scenarios during the far future.

\begin{tabular}{|c|c|c|c|}
\hline Province name & $\begin{array}{l}\text { Percentage } \\
\text { of very } \\
\text { high hazard } \\
\text { area under } \\
\text { RCP4.5 }\end{array}$ & $\begin{array}{l}\text { Percentage } \\
\text { of very } \\
\text { high hazard } \\
\text { area under } \\
\text { RCP8.5 }\end{array}$ & $\begin{array}{r}\text { Percentage } \\
\text { increase } \\
\text { in very } \\
\text { high hazard } \\
\text { area between } \\
\text { RCP8.5 and } 4.5\end{array}$ \\
\hline Attapeu & $0.25 \%$ & $0.25 \%$ & $1.36 \%$ \\
\hline Bokeo & $0.07 \%$ & $0.07 \%$ & $1.42 \%$ \\
\hline Bolikhamsai & $0.37 \%$ & $0.41 \%$ & $11.90 \%$ \\
\hline Champasak & $0.23 \%$ & $0.24 \%$ & $2.77 \%$ \\
\hline Houaphan & $0.24 \%$ & $0.25 \%$ & $3.78 \%$ \\
\hline Khammouan & $0.36 \%$ & $0.41 \%$ & $12.47 \%$ \\
\hline Luang Namtha & $0.08 \%$ & $0.08 \%$ & $1.60 \%$ \\
\hline Luang Prabang & $0.21 \%$ & $0.21 \%$ & $0.99 \%$ \\
\hline Oudomxai & $0.12 \%$ & $0.13 \%$ & $0.66 \%$ \\
\hline Phongsaly & $0.12 \%$ & $0.12 \%$ & $1.13 \%$ \\
\hline Salavan & $0.13 \%$ & $0.13 \%$ & $0.59 \%$ \\
\hline Savannakhet & $0.42 \%$ & $0.46 \%$ & $10.72 \%$ \\
\hline Vientiane Province & $0.34 \%$ & $0.37 \%$ & $8.33 \%$ \\
\hline Vientiane Prefecture & $0.04 \%$ & $0.04 \%$ & $0.75 \%$ \\
\hline Xaignabouli & $0.21 \%$ & $0.21 \%$ & $0.62 \%$ \\
\hline Xekong & $0.15 \%$ & $0.15 \%$ & $0.77 \%$ \\
\hline Xiangkhouang & $0.18 \%$ & $0.18 \%$ & $1.00 \%$ \\
\hline $\begin{array}{l}\text { Total percentage of very } \\
\text { high hazard area } \\
\text { across the country }\end{array}$ & $3.52 \%$ & $3.71 \%$ & \\
\hline
\end{tabular}

for central Italy. The model is based on the relationship between rainfall and soil moisture conditions (Ponziani et al., 2012). Based on above-cited studies, those outputs have similarities to this study's results. It is probable that the precipitation increase is the key factor responsible for hazard area increase in the future projection.

The existing studies on multi-hazard mapping mainly focus on aggregating all individual hazards with equal weight, the sum of the hazard indexes from individual hazards, or using the frequency of occurrence for each hazard to decide the weight, which does not sufficiently reflect the various impacts of different hazards present in the same area. In addition, those studies have not considered the participation of stakeholders. New concepts in this study are that we take into account the opinions of stakeholders by comparing each individual hazard to find the importance of each hazard. The importance of each individual hazard was determined by the AHP method. Furthermore, AHP is a method that attempts to imitate human rationality for decision making by using experiences and perceptions from stakeholders and experts. It offers the organization of knowledge, simplifies structures for understanding the issue and consistency, and involves human logic and intuition as well as experiences. In addition, the pairwise comparisons help stakeholders and experts focus their judgment on each comparison criterion. Each criterion has a certain value that represents a judgment of the likelihood of its scale of importance compared to the others. 
(a)

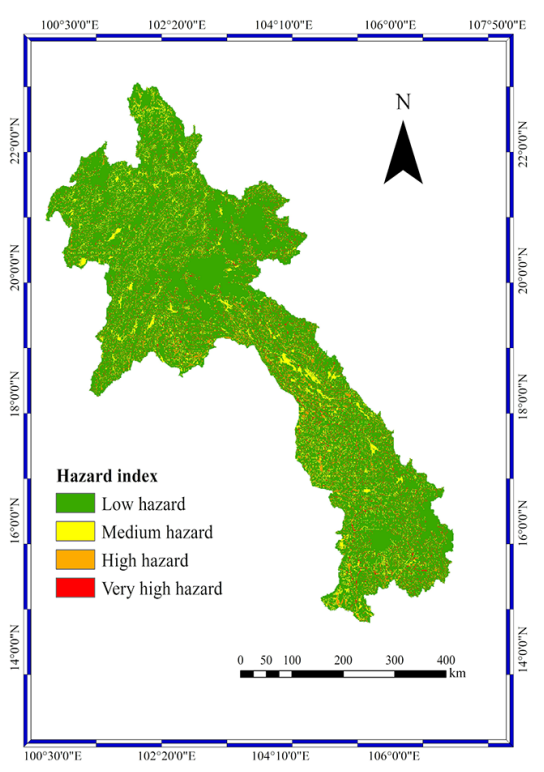

(d)

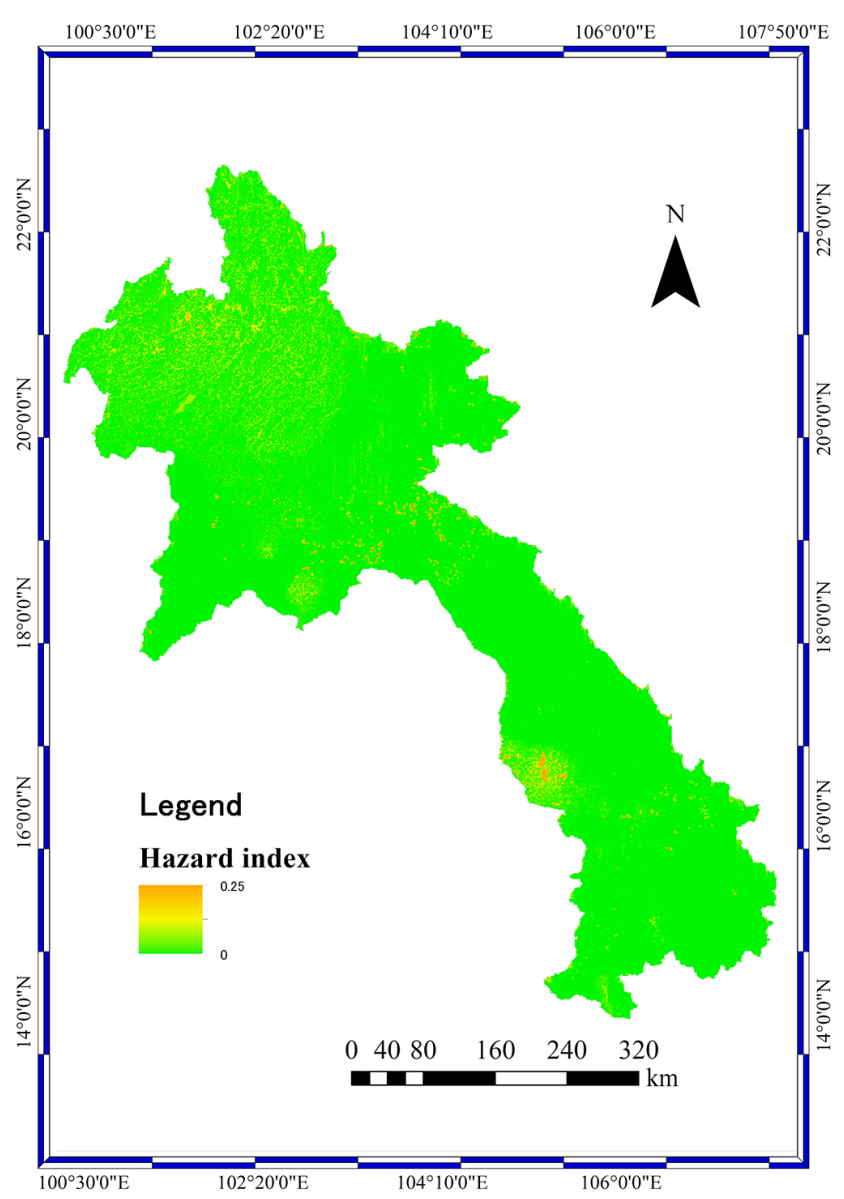

(b)

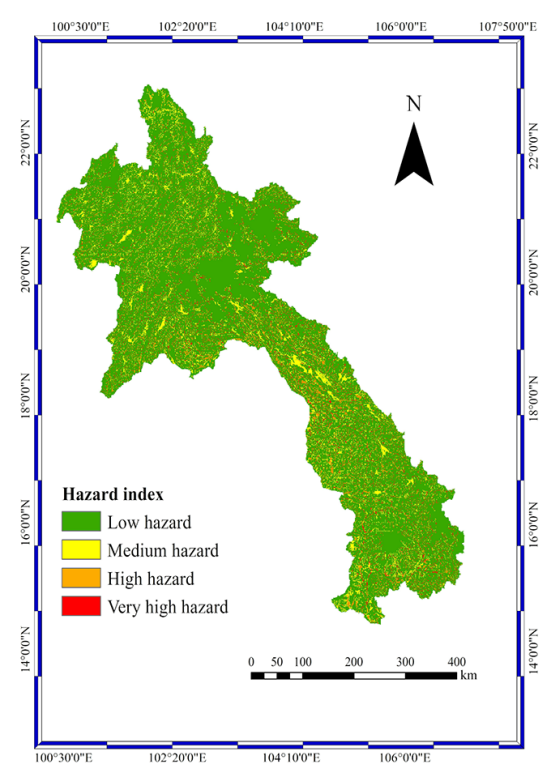

(e)

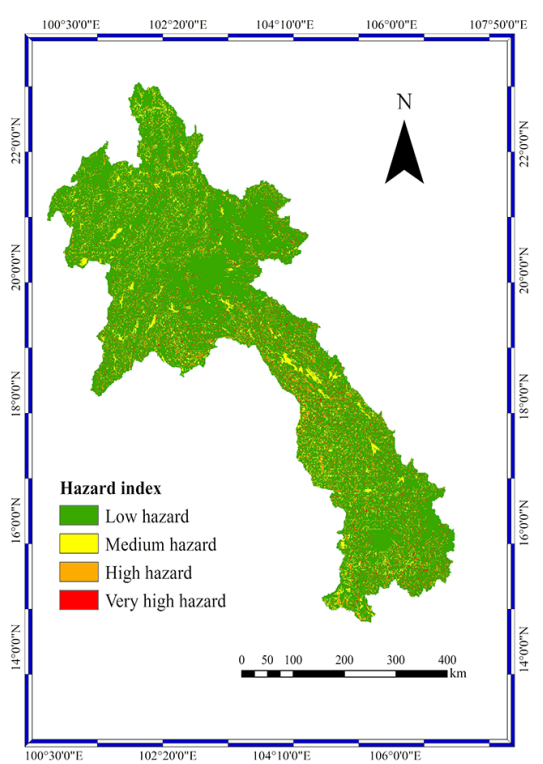

(c) 
(a)

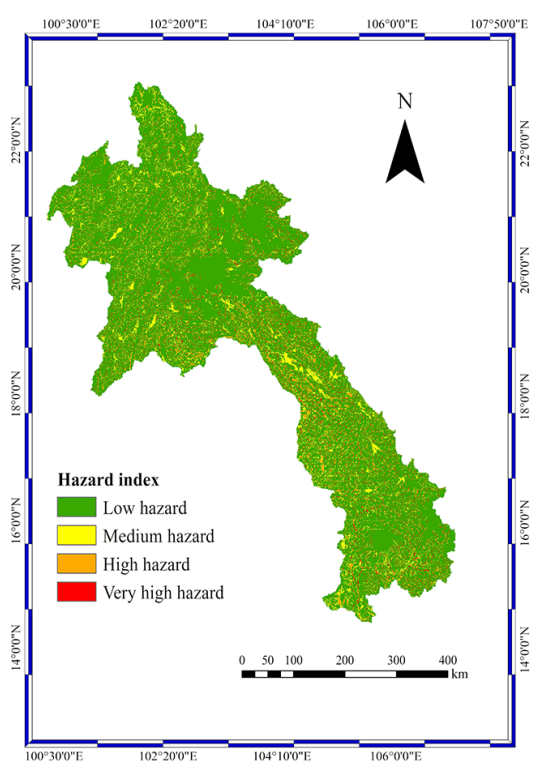

(d)

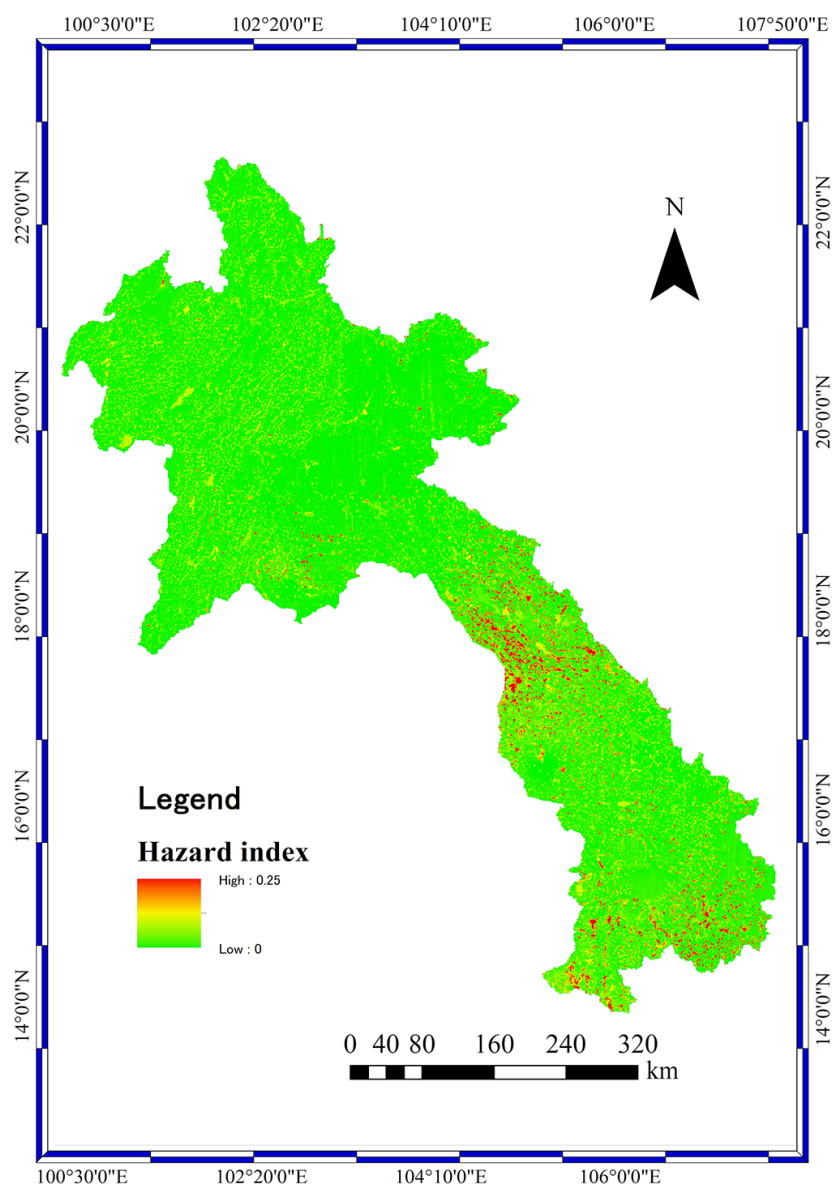

(b)

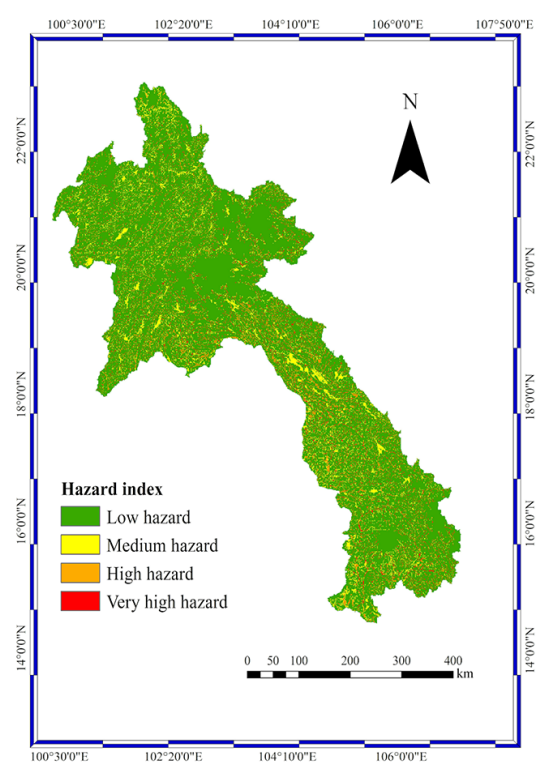

(e)

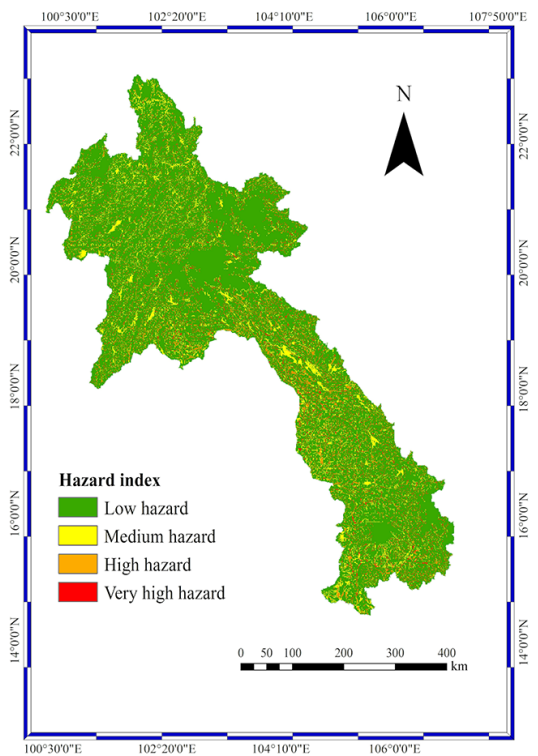

(c) 
The integrated hazard map based on AHP can identify the potential distribution of hazard areas across the country. In addition, the integrated map can provide the preliminary results for the distribution pattern of hazard areas; furthermore, the damage cost from the potential risk area can be estimated. Moreover, the integrated hazard map can be used in combination with other maps, such as the future development plan from the government or private sectors. In this way, the areas of hazard in the development of agricultural areas or the expansion of urban areas could be verified. These maps are applicable to the presentation of the spatial distribution of hazard areas.

\section{Conclusions}

The main objective of this study was to develop an integrated hazard map that is reliable at the national scale. The integrated maps apply the AHP method for integrating all individual hazard maps together, namely, flooding, land use change, landslides, and climate change impacts on flood hazards and climate change impacts on landslide hazard maps. This study provides a significant and valid methodology for the development of integrated hazard maps using multicriteria decision analysis, such as AHP. The results from integrated hazard maps can identify dangerous areas from both individual and integrated hazards. In addition, the results can be used as primary data for screening and selecting development areas. Based on the integrated hazard map, the following results are obtained:

- The southern region has high- and very high hazard areas compared with the central region and the northern region. The northern region has the lowest-hazard area among three regions.

- Total very high hazard area on the integrated hazard map with the anticipated change increases from $3.2 \%$ for RCP2.6 to $3.27 \%$ for RCP4.5 and up to $3.3 \%$ for RCP8.5 in the near-future (2010-2050) scenario. For the far-future (2051-2099) scenario, the very high hazard area increases from $3.23 \%$ for RCP2.6 to $3.52 \%$ for RCP4.5 and up to $3.71 \%$ for RCP8.5.

There are some limitations of the AHP approach. The AHP approach supposes linear independence of alternatives and criteria. It is recommended for future studies to make a comparison between AHP and other multicriteria decisionmaking approaches. Moreover, for modeling the hazard map in a smaller area, topographic information should have higher resolution for better understanding the hazard by local people.

It should be noted that data on population and economic impacts in hazard areas are not yet included in this study. Together with population and economic data in hazard areas, risk areas could be identified.
Code availability. Considered software and models that are not in the public domain are available for research purposes upon request to the authors.

Data availability. Data that are not in the public domain are available for research purposes upon request to the authors.

Supplement. The supplement related to this article is available online at: https://doi.org/10.5194/nhess-21-1551-2021-supplement.

Author contributions. All authors (SP, SK, and DK) contributed to this paper. SP and SK discussed and wrote the initial draft of the paper. SK and DK contributed with meteorological expertise, such as selecting which data to use and meteorological features. SK provided supervision from a meteorological perspective. All authors participated in drafting the article and revising it critically for important intellectual content. All authors gave the final approval of the published version.

Competing interests. The authors declare that they have no conflict of interest.

Acknowledgements. This research was partially supported by the Grants-in-Aid for Scientific Research (B), 2015-2017 (15H05218, So Kazama), from the Ministry of Education, Culture, Sports, Science and Technology. The authors thank the Environmental Research and Technology Development Fund (s-14) from the Ministry of the Environment, Japan. Special thanks are extended to Sengprasong Phrakonkham for his support and assistance in conducting questionnaires for the AHP analysis.

Financial support. The article was funded through the Grantsin-Aid for Scientific Research (B), 2015-2017 (15H05218, 70 So Kazama), from the Ministry of Education, Culture, Sports, Science and Technology and the Environmental Research and Technology Development Fund from the Ministry of the Environment, Japan.

Review statement. This paper was edited by Animesh Gain and reviewed by Ashraf Dewan and one anonymous referee. 


\section{References}

Adeloye, A., Nawaz, N. R., and Bellerby, T. J.: Modelling the impact of climate change on water systems and implications for decision-makers, Climate Change Modelling, Mitigation, and Adaptation, 299-326, https://doi.org/10.1061/9780784412718, 2013..

Adnan, M. S. G., Abdullah, A. Y. M., Dewan, A., and Hall, J. W.: The effects of changing land use and flood hazard on poverty in coastal Bangladesh, Land Use Policy, https://doi.org/10.1016/j.landusepol.2020.104868, in press, 2020 .

Asadzadeh, A., Sikder, S. K., Mahmoudi, F., and Kötter, T.: Assessing Site Selection of New Towns Using TOPSIS Method under Entropy Logic: A Case study: New Towns of Tehran Metropolitan Region (TMR), Environ. Manage. Sustain. Dev., 3, 123-137, https://doi.org/10.5296/emsd.v3i1.4874, 2014.

Asadzadeh, A., Kötter, T., and Zebardast, E.: An augmented approach for measurement of disaster resilience using connective factor analysis and analytic network process (F’ANP) model, Int. J. Disast. Risk Reduct., 99, 104868, https://doi.org/10.1016/j.ijdrr.2015.10.002, 2015.

Baird, I. G. and Shoemaker, B.: Unsettling Experiences: Internal Resettlement and International Aid Agencies in Laos, Dev. Change, 38, 865-888, https://doi.org/10.1111/j.14677660.2007.00437.x, 2007.

Bednarik, M., Magulová, B., Matys, M., and Marschalko, M.: Landslide susceptibility assessment of the Kral'ovany-Liptovský Mikuláš railway case study, Phys. Chem. Earth Pt. A/B/C, 35, 162-171, https://doi.org/10.1016/j.pce.2009.12.002, 2010.

Behzadian, M., Khanmohammadi Otaghsara, S., Yazdani, M., and Ignatius, J.: A state-of the-art survey of TOPSIS applications, Exp. Syst. Appl., 39, 13051-13069, https://doi.org/10.1016/j.eswa.2012.05.056, 2012.

Boé, J., Terray, L., Habets, F., and Martin, E.: Statistical and dynamical downscaling of the Seine basin climate for hydro-meteorological studies, Int. J. Climatol., 27, 1643-1655, https://doi.org/10.1002/joc.1602, 2007.

Bouwer, L. M., Bubeck, P., and Aerts, J. C. J. H.: Changes in future flood risk due to climate and development in a Dutch polder area, Global Environ. Change, 20, 463-471, https://doi.org/10.1016/j.gloenvcha.2010.04.002, 2010.

Ceballos-Silva, A. and López-Blanco, J.: Delineation of suitable areas for crops using a Multi-Criteria Evaluation approach and land use/cover mapping: a case study in Central Mexico, Agric. Syst., 77, 117-136, https://doi.org/10.1016/S0308-521X(02)00103-8, 2003.

Ciabatta, L., Camici, S., Brocca, L., Ponziani, F., Stelluti, M., Berni, N., and Moramarco, T.: Assessing the impact of climate-change scenarios on landslide occurrence in Umbria Region, Italy, J. Hydrol., 541, 285-295, https://doi.org/10.1016/j.jhydrol.2016.02.007, 2016.

Constantin, M., Bednarik, M., Jurchescu, M. C., and Vlaicu, M.: Landslide susceptibility assessment using the bivariate statistical analysis and the index of entropy in the Sibiciu Basin (Romania), Environ. Earth Sci., 63, 397-406, https://doi.org/10.1007/s12665-010-0724-y, 2011.

Cutter, S. L., Mitchell, J. T., and Scott, M. S.: Revealing the Vulnerability of People and Places: A Case Study of Georgetown
County, South Carolina, Ann. Assoc. Am. Geogr., 90, 713-737, https://doi.org/10.1111/0004-5608.00219, 2000.

Dallo, I., Stauffacher, M., and Marti, M.: What defines the success of maps and additional information on a multihazard platform?, Int. J. Disast. Risk Reduct., 49, 101761, https://doi.org/10.1016/j.ijdrr.2020.101761, 2020.

Dankers, R. and Feyen, L.: Climate change impact on flood hazard in Europe: An assessment based on high-resolution climate simulations, J. Geophys. Res.-Atmos., 113, D19105, https://doi.org/10.1029/2007JD009719, 2008.

Dilley, M., Chen, R. S., Deichmann, U., Lerner-Lam, A., Arnold, M., Agwe, J., Buys, P., Kjekstad, O., Lyon, B., and Yetman, G.: Natural disaster hotspots: A global risk analysis, World Bank Disaster Risk Manag. Ser., Washington, DC, 2005.

Dinh, Q., Balica, S., Popescu, I., and Jonoski, A.: Climate change impact on flood hazard, vulnerability and risk of the Long Xuyen Quadrangle in the Mekong Delta, Int. J. River Basin Manage., 10, 103-120, https://doi.org/10.1080/15715124.2012.663383, 2012.

Erener, A. and Düzgün, H. S. B.: Improvement of statistical landslide susceptibility mapping by using spatial and global regression methods in the case of More and Romsdal (Norway), Landslides, 7, 55-68, https://doi.org/10.1007/s10346-009-0188$\mathrm{x}, 2010$.

Fajar Januriyadi, N., Kazama, S., Riyando Moe, I., and Kure, S.: Evaluation of future flood risk in Asian megacities: a case study of Jakarta, Hydrol. Res. Lett., 12, 14-22, https://doi.org/10.3178/hrl.12.14, 2018.

Falaschi, F., Giacomelli, F., Federici, P. R., Puccinelli, A., D'Amato Avanzi, G., Pochini, A., and Ribolini, A.: Logistic regression versus artificial neural networks: landslide susceptibility evaluation in a sample area of the Serchio River valley, Italy, Nat. Hazards, 50, 551-569, https://doi.org/10.1007/s11069-0099356-5, 2009.

Fang, G. H., Yang, J., Chen, Y. N., and Zammit, C.: Comparing bias correction methods in downscaling meteorological variables for a hydrologic impact study in an arid area in China, Hydrol. Earth Syst. Sci., 19, 2547-2559, https://doi.org/10.5194/hess-19-25472015, 2015.

Fernández, D. S. and Lutz, M. A.: Urban flood hazard zoning in Tucumán Province, Argentina, using GIS and multicriteria decision analysis, Eng. Geol., 111, 90-98, https://doi.org/10.1016/j.enggeo.2009.12.006, 2010.

Fishburn, P. C.: Additive Utilities with Incomplete Product Set: Applications to Priorities and Assignments, Operations Research Society of America - ORSA, Baltimore, MD, USA, p. 445, 1967.

Gigović, L., Pamučar, D., Bajić, Z., and Drobnjak, S.: Application of GIS-Interval Rough AHP Methodology for Flood Hazard Mapping in Urban Areas, Water, 9, 360, https://doi.org/10.3390/w9060360, 2017.

Huntington, T. G.: Evidence for intensification of the global water cycle: Review and synthesis, J. Hydrol., 319, 83-95, https://doi.org/10.1016/j.jhydrol.2005.07.003, 2006.

Huynh, V. C.: Multicriteria land suitability evaluation for crops using GIS at community level in central Vietnam with case study in Thuy Bang-Thua Thien Hue province, Hanoi, Vietnam, 2008.

Hwang, C. L. and Yoon, K.: Multiple Attribute Decision Making: Methods and Applications, Springer-Verlag, New York, 1981.

IPCC: Climate change 2007: mitigation of climate change: contribution of Working Group III to the Fourth Assessment $455 \mathrm{Re}$ - 
port of the Intergovernmental Panel on Climate Change, Cambridge University Press, Cambridge, 2007.

Jongman, B., Kreibich, H., Apel, H., Barredo, J. I., Bates, P. D., Feyen, L., Gericke, A., Neal, J., Aerts, J. C. J. H., and Ward, P. J.: Comparative flood damage model assessment: towards a European approach, Nat. Hazards Earth Syst. Sci., 12, 3733-3752, https://doi.org/10.5194/nhess-12-3733-2012, 2012.

Kawagoe, S., Kazama, S., and Sarukkalige, P. R.: Probabilistic modelling of rainfall induced landslide hazard assessment, Hydrol. Earth Syst. Sci., 14, 1047-1061, https://doi.org/10.5194/hess-14-1047-2010, 2010.

Kazakis, N., Kougias, I., and Patsialis, T.: Assessment of flood hazard areas at a regional scale using an index-based approach and Analytical Hierarchy Process: Application in RhodopeEvros region, Greece, Sci. Total Environ., 538, 555-563, https://doi.org/10.1016/j.scitotenv.2015.08.055, 2015.

Keeney, R. L. and Raiffa, H.: Decisions with Multiple Objectives, Cambridge University Press, Cambridge, New York, 465-475, https://doi.org/10.1002/bs.3830390206, 1993.

Komori, D., Rangsiwanichpong, P., Inoue, N., Ono, K., Watanabe, S., and Kazama, S.: Distributed probability of slope failure in Thailand under climate change, Clim. Risk Manage., 20, 126137, https://doi.org/10.1016/j.crm.2018.03.002, 2018.

Konidari, P. and Mavrakis, D.: A multi-criteria evaluation method for climate change mitigation policy instruments, Energ. Policy, 35, 6235-6257, https://doi.org/10.1016/j.enpol.2007.07.007, 2007.

Lafon, T., Dadson, S., Buys, G., and Prudhomme, C.: Bias correction of daily precipitation simulated by a regional climate model: a comparison of methods, Int. J. Climatol., 33, 13671381, https://doi.org/10.1002/joc.3518, 2013.

Lauri, H., de Moel, H., Ward, P. J., Räsänen, T. A., Keskinen, M., and Kummu, M.: Future changes in Mekong River hydrology: impact of climate change and reservoir operation on discharge, Hydrol. Earth Syst. Sci., 16, 4603-4619, https://doi.org/10.5194/hess-16-4603-2012, 2012.

Marzocchi, W., Garcia-Aristizabal, A., Gasparini, P., Mastellone, M. L., and Di Ruocco, A.: Basic principles of multi-risk assessment: a case study in Italy, Nat. Hazards, 62, 551-573, https://doi.org/10.1007/s11069-012-0092-x, 2012.

Mirza, M. M. Q.: Climate change, flooding in South Asia and implications, Reg. Environ. Change, 11, 95--107, https://doi.org/10.1007/s10113-010-0184-7, 2011.

Mohan, V. R., Jeyaseelan, A., Raj, T. N., Narmatha, T., Jayaprakash, M., Madras, U., Campus, G., and Chennai: Landslide susceptibility mapping using frequency ratio method and GIS in south eastern part of Nilgiri District, Tamilnadu, India, Int. J. Geomat. Geosci., 1, 951-961, 2011.

Ohlmacher, G. C. and Davis, J. C.: Using multiple logistic regression and GIS technology to predict landslide hazard in northeast Kansas, USA, Eng. Geol., 69, 331-343, https://doi.org/10.1016/S0013-7952(03)00069-3, 2003.

Ono, K., Akimoto, T., Gunawardhana, L. N., Kazama, S., and Kawagoe, S.: Distributed specific sediment yield estimations in Japan attributed to extreme-rainfall-induced slope failures under a changing climate, Hydrol. Earth Syst. Sci., 15, 197-207, https://doi.org/10.5194/hess-15-197-2011, 2011.
Parmesan, C. and Yohe, G.: A globally coherent fingerprint of climate change impacts across natural systems, Nature, 421, 37-42, https://doi.org/10.1038/nature01286, 2003.

Parry, J. A., Ganaie, S. A., and Sultan Bhat, M.: GIS based land suitability analysis using AHP model for urban services planning in Srinagar and Jammu urban centers of J-K, India, J. Urban Manage., 7, 46-56, https://doi.org/10.1016/j.jum.2018.05.002, 2018.

Phrakonkham, S., Kazama, S., Komori, D., and Sopha, S.: Distributed Hydrological Model for Assessing Flood Hazards in Laos, J. Water Resour. Prot., 11, 937-958, https://doi.org/10.4236/jwarp.2019.118056, 2019.

Ponziani, F., Pandolfo, C., Stelluti, M., Berni, N., Brocca, L., and Moramarco, T.: Assessment of rainfall thresholds and soil moisture modeling for operational hydrogeological risk prevention in the Umbria region (central Italy), Landslides, 9, 229-237, https://doi.org/10.1007/s10346-011-0287-3, 2012.

Pourghasemi, H. R., Mohammady, M., and Pradhan, B.: Landslide susceptibility mapping using index of entropy and conditional probability models in GIS: Safarood Basin, Iran, Catena, 97, 7184, https://doi.org/10.1016/j.catena.2012.05.005, 2012.

Pourkhabbaz, H. R., Javanmardi, S., and Faraji Sabokbar, H. A.: Suitability analysis for determining potential agricultural land use by the multi-criteria decision making models SAW and VIKOR-AHP (case study: takestan-Qazvin plain, J. Agric. Sci. Technol., 16, 1005-1016, 2014.

Prakash, T.: Land Suitability Analysis for Agricultural Crops: A Fuzzy Multicriteria Decision Making Approach, available at: https://pdfs.semanticscholar.org/0ea0/ 1f638e71f9e514d90ad989c5246dd0a0e5db.pdf?_ga=2. 122219535.564011215.1575598334-1946236735.1571628183 (last access: 6 May 2021), 2003.

Priest, S., Tapsell, S., Penning-Rowsell, E., Viavattene, C., and Wilson, T.: Building Models to Estimate Loss of Life for Flood Events, FLOODsite, available at: https://www.researchgate. net/publication/257343008_Building_Models_to_Estimate_

Loss_of_Life_for_Flood_Events/citation/download (last access: 6 May 2021), 2008.

Qin, X. S., Huang, G. H., Chakma, A., Nie, X. H., and Lin, Q. G.: A MCDM-based expert system for climate-change impact assessment and adaptation planning - A case study for the Georgia Basin, Canada, Exp. Syst. Appl., 34, 2164-2179, https://doi.org/10.1016/j.eswa.2007.02.024, 2008.

Ramya, S. and Devadas, V.: Integration of GIS, AHP and TOPSIS in evaluating suitable locations for industrial development: A case of Tehri Garhwal district, Uttarakhand, India, J. Clean. Prod., 238, 117872, https://doi.org/10.1016/j.jclepro.2019.117872, 2019.

Saaty, T. L.: How to make a decision: The analytic hierarchy process, Eur. J. Oper. Res., 48, 9-26, https://doi.org/10.1016/03772217(90)90057-I, 1990.

Saaty, T. L. and Vargas, L. G.: Decision Making with the Analytic Network Process Economic, Political, Social and Technological Applications with Benefits, Opportunities, Costs and Risks, Springer, New York, 2006.

Salem, G. S. A., Kazama, S., Shahid, S. and Dey, N. C.: Groundwater-dependent irrigation costs and benefits for adaptation to global change, Mitig. Adapt. Strateg. Glob. Change, 23, 953-979, https://doi.org/10.1007/s11027-017-9767-7, 2018. 
Sendai Framework: Sendai Framework for Disaster Risk Reduction 2015-2030, available at: https://www.unisdr.org/files/ 43291_sendaiframeworkfordrren.pdf (last access: 6 May 2021), 2015.

Shah, M. I., Khan, A., Akbar, T. A., Hassan, Q. K., Khan, A. J., and Dewan, A.: Predicting hydrologic responses to climate changes in highly glacierized and mountainous region Upper Indus Basin, Roy. Soc. Open Sci., 7, 191957, https://doi.org/10.1098/rsos.191957, 2020.

Sidle, R. C. and Ochiai, H.: Landslides: Processes, Prediction, and Land Use, American Geophysical Union, Washington, D.C., 2006.

Stefanidis, S. and Stathis, D.: Assessment of flood hazard based on natural and anthropogenic factors using analytic hierarchy process (AHP), Nat. Hazards, 68, 569-585, https://doi.org/10.1007/s11069-013-0639-5, 2013.

Sullivan-Wiley, K. A. and Short Gianotti, A. G.: Risk Perception in a Multi-Hazard Environment, World Dev., 97, 138-152, https://doi.org/10.1016/j.worlddev.2017.04.002, 2017.

Tate, E., Cutter, S. L., and Berry, M.: Integrated Multihazard Mapping, Environ. Plan. B, 37, 646-663, https://doi.org/10.1068/b35157, 2010. van Westen, C. J., van Asch, T. W. J., and Soeters, R.: Landslide hazard and risk zonation - why is it still so difficult?, Bull. Eng. Geol. Environ., 65, 167-184, https://doi.org/10.1007/s10064005-0023-0, 2006.

Westra, S., Fowler, H. J., Evans, J. P., Alexander, L. V, Berg, P., Johnson, F., Kendon, E. J., Lenderink, G., and Roberts, N. M.: Future changes to the intensity and frequency of short-duration extreme rainfall, Rev. Geophys., 52, 522-555, https://doi.org/10.1002/2014RG000464, 2014.

Winsemius, H. C., Aerts, J. C. J. H., van Beek, L. P. H., Bierkens, M. F. P., Bouwman, A., Jongman, B., Kwadijk, J. C. J., Ligtvoet, W., Lucas, P. L., van Vuuren, D. P., and Ward, P. J.: Global drivers of future river flood risk, Nat. Clim. Change, 6, 381-385, https://doi.org/10.1038/nclimate2893, 2016.

Yousefi, S., Pourghasemi, H. R., Emami, S. N., Pouyan, S., Eskandari, S., and Tiefenbacher, J. P.: A machine learning framework for multi-hazards modeling and mapping in a mountainous area, Sci. Rep., 10, 12144, https://doi.org/10.1038/s41598-020-692332, 2020. 